\title{
The Knowledge and reported vaccination status of hepatitis B virus amongst medical students in a Nigerian tertiary teaching hospital
}

\author{
*Adeleye, O.O. ${ }^{1}$, Oyelekan, A.A. ${ }^{2}$, Ale, A.O. ${ }^{1}$, Olaitan, A.O. ${ }^{1}$, Ayanwale, A. ${ }^{1}$
}

\begin{abstract}
Objective: Preventing the occupational risk of contracting the Hepatitis B virus (HBV) is against a backdrop of knowledge and vaccination. The aim of the study was to assess the knowledge of the medical students on HBV infection and their vaccination status.
\end{abstract}

Method: A cross-sectional study on was conducted using a self-administered questionnaire. Data of 202 students were analyzed using SPSS v. 20. Descriptive statistical tests were applied.

Result: Subjects' ages ranged from 19 to 36 years, mean age of $25.65 \pm 3.3$ years, $54.1 \%$ were males. The knowledge score on general knowledge was $79.2 \%$, on risks factors and mode of transmission of virus was $74.9 \%$ whilst on prevention was $89 \%$. The reported vaccination status was $22.8 \%$. Eighty one of them (40.1\%) had been tested for the HBV with 4(4.9\%) testing positive.

Conclusion: The medical students had good knowledge of the Hepatitis B virus however the vaccination status was low.

Keywords: Chronic Hepatitis B, Health care workers, mode of transmission,

\author{
*Correspondence author \\ DrAdeleye O.O. \\ http://orcid.org/0000-0001-6069-5850 \\ Email: funtos2000@yahoo.co.uk. \\ 'Department of Medicine, Olabisi Onabanjo University Teaching Hospital, Sagamu, Nigeria. \\ ${ }^{2}$ Department of Surgery, Olabisi Onabanjo University Teaching Hospital, Sagamu, Nigeria.
}




\title{
Connaissance et statut vaccinal du virus de l'hépatite $B$ chez des étudiants en médecine d'un établissement d'enseignement supérieur nigérian
}

\author{
*Adeleye, O.O. ${ }^{1}$, Oyelekan, A.A. ${ }^{2}$, Ale, A.O. ${ }^{1}$, Olaitan, A.O. ${ }^{1}$, Ayanwale, A. ${ }^{1}$
}

\begin{abstract}
Abstrait
Objectif: le risque professionnel de contracter l'hépatite B peut être prévenu par une éducation adéquate en matière d'infection, qui influence l'attitude et la couverture vaccinale.

Objectif: évaluer les connaissances des étudiants en médecine et leur statut vaccinal.
\end{abstract}

Méthodes: Un questionnaire structuré a été utilisé pour obtenir les réponses des étudiants en médecine. Résultat: sur les 207 étudiants en médecine, âgés de 19 à 36 ans (âge moyen $=25,65 \pm 3,3$ ans), seuls $25 \%$ ont correctement identifié tous les modes de transmission; 97,5\% pensaient que le vaccin conférait une protection contre le virus, mais $22,2 \%$ seulement des étudiants en médecine étaient vaccinés. Comparativement, les étudiants en médecine des années V et VI avaient une connaissance plus générale et le mode de transmission de l'hépatite $\mathrm{B}$ que l'année IV $(\mathrm{p}=0,00)$.

Conclusion: cette étude a révélé la vulnérabilité des étudiants en médecine à l'hépatite $B$ en raison de la connaissance insuffisante du mode de transmission du virus et de la faible couverture vaccinale.

Mots-clés: Hépatite B chronique, travailleurs de la santé, mode de transmission,

\footnotetext{
*Auteur principal

Dr Adeleye O.O.

http://orcid.org/0000-0001-6069-5850

Email: funtos2000@yahoo.co.uk.

'Department of Medicine, Olabisi Onabanjo University Teaching Hospital, Sagamu, Nigeria.

${ }^{2}$ Department of Surgery, Olabisi Onabanjo University Teaching Hospital, Sagamu, Nigeria.
} 


\section{INTRODUCTION}

Hepatitis B virus (HBV) infection is a major global health challenge with an estimated 240 million people chronically infected with hepatitis B and approximately 780,000 people die each year due to consequences of hepatitis B (1). The prevalence of HBV chronic infection is particularly high in sub-Saharan Africa, ranging from 7 to $26 \%$ (2). In Nigeria, the prevalence of HBV ranges from 7.3-24\% of the population (3). Sexual transmission, vertical transmission, and unsafe injections, including intravenous drug use, are the most common routes of infection for HBV.

Hepatitis B virus is an important occupational hazard for healthcare workers (HCW); medical students are likely to be at high risk to get and spread HBV because their activities involve contact with patients or blood or other body fluids in healthcare practice and laboratories (4-6). The risk of contracting the infection is said to be highest during their professional training (7-9) and it is acquired in the hospital setting via needle prick injuries from contaminated needles, eye contact with infected body fluids or from contact of infected body fluids with broken skin (10). Prevention is the only safe strategy against high prevalence of the viral hepatitis. Having enough knowledge and proper attitudes toward this infection and vaccination are the cornerstones of preventing transmission. Medical students have a very important role in preventing the disease by improving the disease knowledge among themselves and the patients they treat (11). As far as we know, there is paucity of data as regards assessment of the knowledge of medical students about the Hepatitis B virus as well as the vaccination situation in Nigeria. It is therefore with this background, this study aimed to determine the knowledge and hepatitis B vaccination status of medical students at a Tertiary Teaching Hospital in Nigeria.

\section{MATERIALS AND METHODS}

Study location and design: Olabisi Onabanjo University Teaching Hospital is 205 bedded hospital situated in Sagamu, Ogun State; she is located in the south western part of Nigeria and receives referrals from both public and private hospitals from Lagos metropolitan and the communities around Sagamu for both inpatient and outpatient care. This was a descriptive cross-sectional study conducted in August 2015 among medical students in their clinical years.
Study Participants and Sampling: Participants were recruited through a non-randomized sampling of eligible medical students who were available during lectures during the period of the study. Eligible participants were students in the clinical years (IV, V and VI). There were one hundred and sixteen, fifty three and one hundred and fifty four medical students in year IV, V and VI classes respectively so that the total numbers of eligible students were three hundred and twenty three. The invitation to participate was made during lectures, generally about $80 \%$ of students attend lectures and therefore only students available during the lectures on different occasions were recruited. The objectives of the study were explained to the participants and they were aware that their participation to fill a selfadministered questionnaire was voluntary. Anonymity was assured to each subject before the students included in the study. Before filling the questionnaire, the students signed an informed consent form (ICF); consenting participants were given printed copies of the questionnaire and allowed time to fill them at their will and convenience. Ethical approval was obtained from the Health Research and Ethics Committee of the Teaching hospital before commencement of study.

For the collection of data, we used a structured questionnaire that was adopted from a previous study (11). The language of instruction at the medical school is English therefore the questionnaire was administered in English Language. The questionnaire consisted of four sections:

1. Socio-demographic and academic characteristics;

2. Knowledge of the HBV;

3. HBV prevention;

4. Vaccination status.

In the context of the present study, we considered participants adequately vaccinated if they had received a minimum of three intramuscular injections of 20 micrograms of HBsAg (hepatitis B surface antigen) at a schedule of 0,1 and 6 months. Their knowledge was considered "good" if the mean percentage of correct answers was equal or greater than $75 \%$, "fair" if it was less than $75 \%$ and equal or greater than $50 \%$, and "poor" if it was less than 50\% (12). The data obtained were analyzed using the statistical package for social science (SPSS) version 20.0. The univariate analysis was performed by descriptive statistics through frequencies and percentages. Categorical variables were expressed as frequency $(\%)$, and 
group comparison were by the Pearson's Chisquare. A p-value of 0.05 or less was used as cut off level for statistical significance.

\section{RESULTS}

Two hundred and fifty eight students were available during lectures and of which 207 $(80.2 \%)$ respondents returned the questionnaire properly filled. The ages of the students ranged from 19 to 36 years with a mean age of 25.65 years \pm 3.3 . Ninety six $(46.4 \%)$ were female. Information on sex was missing for one participant $(0.5 \%)$. Eight $(3.9 \%)$ of them were married while one hundred and ninety nine of them were single $(96.1 \%)$. See table 1 for demographic characteristics of the participants.

\section{General Knowledge of Chronic Hepatitis B.}

The study revealed that 202(97.6\%) were aware or had heard of chronic hepatitis B virus infection. As regards the general knowledge on Hepatitis B, the knowledge score was 79.2\% which was good. Out of those aware of the virus, $195(96.5 \%)$ knew it was of viral origin. One hundred and twelve (55.4\%) of the students knew that chronic Hepatitis B was mostly asymptomatic and $156(77.2 \%)$ responded that patients with hepatitis B should be allowed to work. The respondents who knew that doctors and medical students were more prone to the infection were $177(87.6 \%)$. See Table 2

\section{Knowledge on Mode of Transmission and Risk Factors of Hepatitis B}

Among all the respondents, as regards the mode of transmission and risk factors of the hepatitis B virus, their knowledge score was fair (74.9\% of correct answers), although only $52(25.7 \%)$ of the students knew all the mode of transmission of the virus and $31(15.3 \%)$ correctly identified all the risk factors associated with contracting the virus. Fifty two(25.7\%) identified dental procedure as a risk factor to contracting Hepatitis B infection when compared to blood transfusion $(183 ; 90.6 \%)$, Piercing and Tattooing (152;75.2\%), Needle pricks $(147 ; 72.8 \%)$ and sexual transmission $(137 ; 67.8 \%)$ and vertical transmission (104; $55.5 \%$. See Table 3 .

\section{Knowledge on Prevention of Hepatitis B and the Vaccination Status}

The knowledge score on the prevention of hepatitis B was good ( $89 \%$ correct answers); $194(96.0 \%)$ responded that hepatitis B infection can be prevented with $189(92.8 \%)$ of them responding that the vaccine confers protection against the HBV, however only $160(79.2 \%)$ knew that the ideal time for receiving immunization against the virus was at infancy. See table 4 . Eighty one of the participants $(40.1 \%)$ had been tested for the HBV infection with $4(4.9 \%)$ of them testing positive. Of the total of 202 students, forty six (22.8\%) were adequately vaccinated against hepatitis $\mathrm{B}$ (received $\geq 3$ doses of the vaccine), forty (19.8\%) had incomplete vaccination (one or two doses of the vaccine), and $116(57.4 \%)$ were unvaccinated (received zero, did not know their vaccination status or did not know the number of vaccine doses received). See Figure 1. Year IV medical students were less vaccinated than years V and VI $(p<0,001)$. There was no significant statistical association between HBV vaccination status and gender $(\mathrm{p}=0.629)$ (Table5). Among the forty students who had incomplete vaccination against hepatitis B, 22 students $(55 \%)$ received one dose while eighteen $(45 \%)$ received two doses.

\section{DISCUSSION}

In this study we sought to assess the knowledge of Hepatitis B as regards the general knowledge, mode of transmission, and the vaccination status of the medical students in their clinical years. We looked at the knowledge of chronic hepatitis $\mathrm{B}$ infection and the reported vaccination status among medical students because their knowledge of the Hepatitis B virus which influences the vaccination status is imperative to reduce the transmission and therefore the burden of HBV related chronic liver disease considering the fact that they have increased risk of acquiring the virus in their clinical years. Most of the medical students were aware or had good general knowledge of the HBV infection which is similar to findings among other health workers in previous studies in Nigeria $(13,14)$; which may be due to a general public awareness as there are increasingly more awareness campaigns of viral hepatitis in the media, apart from the fact that they would have been taught as part of their lectures. Our findings also revealed that majority of the responses indicate adequate knowledge regarding some modes of HBV transmission for example blood transfusion (90.3\%), Piercing and Tattooing $(74.9 \%)$, Needle pricks $(72.5 \%)$ and sexual $(67.6 \%)$ while the knowledge of dental visits as a risk factor for transmission of $\mathrm{HBV}$ was low at $25.1 \%$. In general, they had a fair knowledge of the mode of transmission and risk factors of the virus. This finding appears to be in contrast with other reported studies where their respondents had general low knowledge of the mode of 
transmission $(12,15,16)$. There is a gap in the knowledge of the medical students regarding all the mode of transmission of this potentially life threatening infection. The plausible reason could be inadequate training programs on prevention and control of HBV. This gap in knowledge needs to be addressed as the scientific knowledge of the modes of HBV transmission is valuable so that the medical students can learn to protect themselves during their clinical posting. (16-19). A significant number of the respondents knew that the disease is preventable and that the vaccine protects against the infection however only $22.8 \%$ of the medical students had been adequately vaccinated, while the rest had incomplete vaccination or were unsure of their vaccination status. The finding of $22.8 \%$ vaccination status in our undergraduates was low and less than studies done in Sweden 40\% (20), Bangladesh (40.7\%) (5), and Saudi Arabia, $52.2 \%$ (4). However the vaccination status was higher than an earlier reported study by Odusanya et al (6) in Nigeria in 2007 where only $2.6 \%$ of their respondents were vaccinated. This might perhaps mean that more awareness of the occupational hazard of the HBV has been created since then albeit still inadequate. A significant proportion, $57.4 \%$ which were classified as unvaccinated consisted of respondents who were unsure of their vaccination status. This finding is similar to a study conducted that examined selfreported vaccination among medical students which revealed that students had poor specific knowledge of their previous vaccinations $(\underline{18})$. It is worrisome that the reported vaccination status among the students is low considering the fact that the need for HBV vaccination among all medical students should be a priority (21-23).

\section{CONCLUSION}

This study demonstrated that the student had a good general knowledge of the Hepatitis B virus, fair knowledge on the mode of transmission and the risk factors in contracting the virus. There was good knowledge on prevention of the virus using vaccine however the reported vaccination status was low among the medical students. There is therefore a need to implement a policy to make vaccination a priority among medical students.

Acknowledgement: All the medical students that participated in this study and senior colleagues who helped in the review of this work.

Conflict of interest: The authors declare none.

\section{REFERENCES}

1. World Health Organization (WHO). Hepatitis B Factsheet Fact sheet $\mathrm{N}^{\circ}$ 204. Updated July 2015. Geneva: WHO. Available at: http://www.who.int/mediacentre/factsheets/fs20 4/en/ (Accessed 17 February 2016).

2. Andre F: Hepatitis B epidemiology in Asia, the Middle East and Africa. Vaccine 2000, 18(1):S20-S22.

3. Malu AO, Borodo MM, Ndububa DA, Ojo OS, Anomneze EE, Lesi OA, et al. Hepatitis B and C treatment guidelines for Nigeria.. Nigerian Journal Of Gastroenterology and Hepatology. 2015;63-75.

4. Al-Hazmi AH. Knowledge, Attitudes, and Practice of Medical Students Regarding Occupational Risks of Hepatitis B Virus in College of Medicine, Aljouf University. Ann Med Health Sci Res. Jan-Feb 2015; 5(1): 13-19.

5. Ahmed MS, Chowdhury OA, Chowdhury AR, Khatoon M. Seroprevalence of HBs antibody among the newly admitted medical students in Bangladesh and seroconversion one year after vaccination. Bangladesh Med Res Counc Bull. 2010;36:41-2.

6. Odusanya OO, Meurice FP, Hoet B. Nigerian medical students are at risk for hepatitis B infection. Trans R Soc Trop Med Hyg. 2007; 101:465-8.

7. Centers for Disease Control and Prevention (CDC). Immunization of health-care personnel: recommendations of the Advisory Committee on Immunization Practices (ACIP). MMWR Recomm Rep. 2011;60(RR-7):1-45.

8. Deisenhammer S, Radon K, Nowak D, Reichert J. Needle stick injuries during medical training. J Hosp Infect. 2006;63:263-7.

9. Patterson JM, Novak CB, Mackinnon SE, Ellis RA.Needle stick injuries among medical students. Am J Infect Control. 2003;31: 226-30.

10. Alavian SM, Mahboobi N. Anti-HBs antibody status and some of its associated factors in dental health care workers in Tehran University of Medical Sciences: Anti-HBs Ab and associated factors in dental society. Hepat Mon. 2011;11(2):99-102.

11. Nazir I and Amr I. "Hepatitis B Awareness among Medical Students and Their Vaccination Status at Syrian Private University. Hepat Res Treat. 2014, ID 131920: 7.

12. Jean Jacques $\mathrm{N}$ Noubiap, Jobert Richie $\mathrm{N}$ Nansseu, Karen K Kengne, Shalom Tchokfe Ndoula, Lucy A Agyingi. Occupational exposure to blood, hepatitis B vaccine knowledge and uptake among medical students in Cameroon. BMC Medical Education 2013, 13: 148

13. Okwara EC, Enwere OO, Diwe CK, Azike JE, Chukwulebe AE. "Theatre and laboratory workers' awareness of and safety practices against hepatitis $\mathrm{B}$ and $\mathrm{C}$ infection in a suburban university teaching hospital in Nigeria.PanAfr MedJ. 2012; 13:2. 
14. Adekanle O, Ndububa D, Olowookere SA,Ijarotimi O, Ijadunola KT.Knowledge of Hepatitis B Virus Infection, Immunization with Hepatitis B Vaccine, Risk Perception, and Challenges to Control Hepatitis among Hospital Workers in a Nigerian Tertiary Hospital, Hepat Res Treat .2015; ID 439867: 6.

15. Yonatan MM, Kelemu TK. Assessment of Knowledge and Practice towardsHepatitis B among Medical and Health Science Studentsin Haramaya University, Ethiopia. PLOS one, Nov 2013; 8: 11

16. Mansour-Ghanaei R, Joukar F, Souti F, AtrkarRoushan Z. Knowledge and attitude of medical science students toward hepatitis B and C infections. Int J ClinExp Med. 2013;6:197-205.

17. Kordi R, Wallace WA. Blood borne infections in sport: Risks of transmission, methods of prevention, and recommendations for hepatitis B vaccination. Br J Sports Med. 2004;38:678-84.

18. Torda AJ. Vaccination and screening of medical students: Results of a student health initiative. Med J Aust. 2008;189:484-6.
19. Khan N, Ahmed SM, Khalid MM, Siddiqui SH, Merchant AA. Effect of gender and age on the knowledge, attitude and practice regarding hepatitis $\mathrm{B}$ and $\mathrm{C}$ and vaccination status of hepatitis B among medical students of Karachi, Pakistan. J Pak Med Assoc. 2010 Jun; 60(6):4505.

20. Dannetun E, Tegnell A, Torner A, Giesecke J. Coverage of hepatitis B vaccination in Swedish healthcare workers. J Hosp Infect. 2006;63:201-4.

21. Carvalho P, Schinoni MI, Andrade J, VasconcelosRego MA, Marques P, Meyer R, et al. Hepatitis $\mathrm{B}$ virus prevalence and vaccination response in health care workers and students at the Federal University of Bahia, Brazil. Ann Hepatol. 2012;11(3):330-7.

22. Mahoney FJ: Update on diagnosis, management and prevention of hepatitis B virus infection. Clin Microbiol Rev 1999, 12(2):351-366.

23. U.S. Public Health Service: Updated U.S. Public health service guide linesfor the management of occupational exposures to HBV, HCV, and HIV and recommendations for post exposure prophylaxis. MMWR Recomm Rep 2001, 50(RR-11):1-52. 
Table 1: Demographic characteristics of 207 study participants.

\begin{tabular}{lll}
\hline Parameter & Number of Subjects & Percentage \\
\hline CLASS & & \\
IV & 70 & 33.8 \\
V & 41 & 19.8 \\
VI & 96 & 46.4 \\
GENDER & & \\
Male & 110 & 53.1 \\
Female & 96 & 46.4 \\
Unspecified & 1 & 0.5 \\
MEAN AGE(SD) & $25.65 \pm 3.3$ & \\
MARITAL STATUS & & \\
Married & 8 & 3.9 \\
Single & 199 & 96.1 \\
\hline
\end{tabular}

Table 2: Responses to questions on general knowledge on Hepatitis B for 202 students.

\begin{tabular}{llll}
\hline QUESTIONS & RESPONSES & FREQUENCY & PERCENTAGE \\
\hline Most cases of chronic & Asymptomatic & 112 & 55.4 \\
Hep B & Symptomatic/do not know & 90 & 44.6 \\
Doc \& students more & Yes & 177 & 87.6 \\
prone to infection & No/ No response & 25 & 12.4 \\
Hepatitis patient & Yes & 156 & 77.2 \\
allowed to work & No/ No response & 46 & 22.8 \\
Causative agent & Virus & 195 & 96.5 \\
& Bacteria & 3 & 1.5 \\
& Protozoa & 1 & 0.5 \\
& Do not know & 3 & 1.5 \\
\hline
\end{tabular}

\begin{tabular}{cllc}
\hline $\begin{array}{c}\text { QUESTION } \\
\text { Table 3: CorRqSSAONSSEson the knowledge on the mode of }\end{array}$ & $\begin{array}{c}\text { CORRECT } \\
\text { transmission and risk factors }\end{array}$ \\
\hline Mode of spread & All mode of transmission & 52 & 25.1 \\
& Blood Transfusion & 183 & 90.6 \\
& Sexual & 121 & 59.9 \\
& Vertical transmission & 104 & 51.5 \\
& Contaminated food & 187 & 92.6 \\
& Physical contact & 156 & 77.2 \\
& Saliva & 156 & 77.2 \\
& & & \\
Aisk factors & 31 & 15 \\
& All risk factors & 179 & 86.5 \\
& Smoking & 149 & 72.0 \\
& Alcohol use & 155 & 74.9 \\
& Piercing \& tattoo & 183 & 90.6 \\
& Blood transfusion & 52 & 25.1 \\
& Dental visit & 194 & 93.7 \\
& Contaminated food & 194 & 93.7 \\
& Contaminated drinks & 150 & 72.5 \\
& Needle pricks & 140 & 67.6 \\
\hline
\end{tabular}


Table 4: Responses to questions on prevention of Hepatitis B

\begin{tabular}{llll}
\hline Questions & Responses & Frequency & Percentage \\
\hline $\begin{array}{l}\text { Hepatitis B } \\
\text { preventable }\end{array}$ & Yes & 198 & 95.7 \\
& No/No response & 7 & 3.4 \\
Vaccine protects & Yes & 189 & 93.6 \\
against the infection & No/ No response & 13 & 6.4 \\
& & & \\
Ideal age of & Infancy & 161 & 77.8 \\
vaccination & Youth & 20 & 9.7 \\
& Adulthood & 7 & 3.4 \\
& No response & 19 & 9.2 \\
\hline
\end{tabular}

Table 5: Comparatively analysis of reported vaccination status among the levels of students and Gender of Students.

\begin{tabular}{llllll}
\hline $\begin{array}{l}\text { Level } \\
\text { of class }\end{array}$ & $\begin{array}{l}\text { Complete } \\
\text { vaccination }\end{array}$ & $\begin{array}{l}\text { Incomplete } \\
\text { vaccination }\end{array}$ & Not vaccinated & X2 & P value \\
\hline VI & $36(37.5)$ & $21(21.9)$ & $39(40.6)$ & 30.81 & 0.0000 \\
V & $8(19.5)$ & $7(17.1)$ & $26(63.4)$ & & \\
IV & $2(3.1)$ & $12(18.5)$ & $51(78.5)$ & & \\
Male & $21(19.4)$ & $21(19.4)$ & $66(61.1)$ & 2.61 & 0.629 \\
Female & $25(26.9)$ & $19(20.4)$ & $49(52.7)$ & & \\
\hline
\end{tabular}

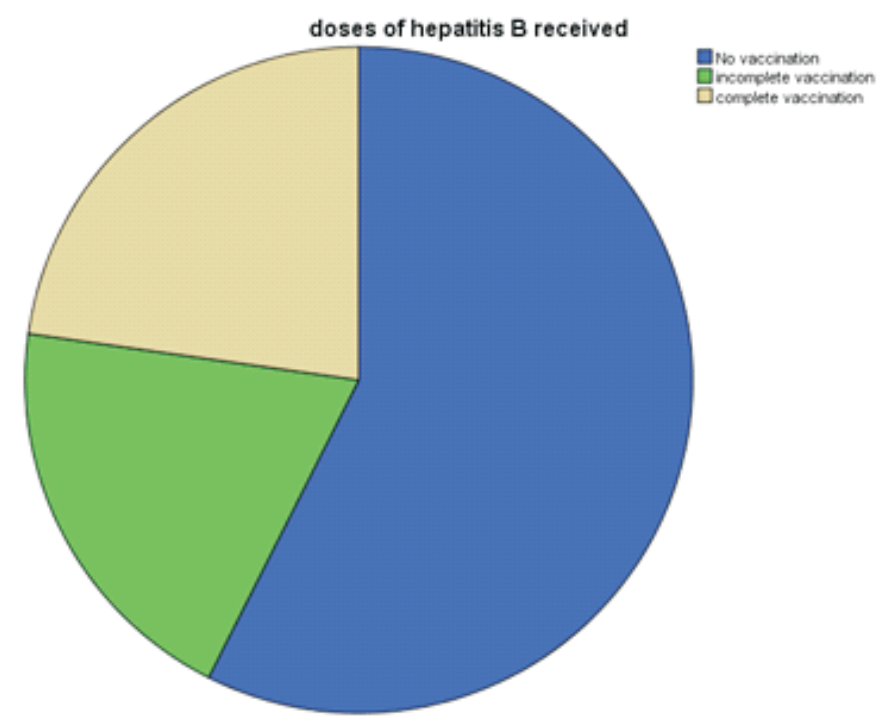

Figure 1: Reported vaccination status among 202 students 